\title{
Differences in Age Estimated by the Kvaal Method on Right and Left Mandibular Canines
}

\author{
Sulistyani Kusumaningrum, Brian Wasita, Hari Wujoso, Rachmi Fauziah \\ Rahayu, Muhamad Lukman Hermansyah, Tharina Lawei
}

Department of Radiology, Department of Anatomical Pathology and Department of Forensics, Dr. Moewardi Hospital / Faculty of Medicine, Universitas Sebelas Maret, Surakarta

\section{ABSTRACT}

Background: The radiographic method for determining the estimated age has the advantage of being non-invasive and the orthopantomogram images are digitally processed. Canines have a strong correlation with chronological age and have good resistance and large pulp space. This study aimed to determine the difference in age estimates using the Kvaal method on the right and left mandibular canines.

Subjects and Method: There were 80 orthopantomogram samples from dental and oral clinic patients who had undergone orthopantomography at the Radiology Installation of Dr. Moewardi Hospital, from January 2019 to December 2020. The estimated age of right and left canines was calculated based on the Kvaal method and performed a Ttest.

Results: At the estimated age of the right and left mandibular canines determined by the Kvaal formula, the T-test was performed showing a mean of 38.3 years for the right mandibular canine
$($ Mean $=38.3 ; \mathrm{SD}=6.7)$ and 38.2 year the left mandibular canine $(\mathrm{Mean}=38.2 ; \mathrm{SD}=8.9$ ), with $\mathrm{p}=0.910$. Data analysis showed that there was no difference in age estimation using the Kvaal method on the right and left mandibular canines.

Conclusion: There was no difference in age estimates by the Kvaal method on the right and left mandibular canines.

Keywords: Oratopantomogram, Metoday Qual, Kaninus Mandibula

\section{Correspondence:}

Sulistyani Kusumaningrum. Department of Radiology Dr. Moewardi Hospital / Faculty of Medicine Universitas Sebelas Maret, Surakarta. Email: kusumasulis1@gmail.com.

\section{Cite this as:}

Kusumaningrum S, Wasita B, Wujoso H, Rahayu RF, Hermansyah ML, Lawei T (2021). Differences in Age Estimated by the Kvaal Method on Right and Left Mandibular Canines. Indones J Med. 06(02): 206-211. https://doi.org/10.26911/theijmed.2021.06.02.09.

\section{cc (†) (2) Indonesian Journal of Medicine is licensed under a Creative Commons}

cc) ${ }_{\mathrm{EY}}$ NG SA Attribution-NonCommercial-ShareAlike 4.o International License.

\section{BACKGROUND}

Dental development research is extensive and various methods have been developed to assess age. Clinical, radiographic based methods can be applied to living individuals, whereas histology and biochemistry are applied to remains. However, these methods have their respective limitations, including: the calculation of the number of erupted teeth is only limited to the estimated age range of 6.8 months (SD 1.56) to 28.21 months (SD 4.47) (Putri et al., 2013); attrition is influenced by the type of food consumed in a population (Miles, 2001 and Putri et al., 2013); Microscopic examination and biochemical methods are invasive, perceptions of change are subjective and require time (Adams et al., 2014; Az, 2016; Madea 2014; Priyadarshni et al., 2015; Putri et al., 2013; Senn and Stimson, 2010; and Stimson and Mertz, 1997). While the radiographic method has advantages, namely it is non-invasive, does not require tooth extraction and the image has been formed digitally so that the measurement process can be carried out using software. 
The method of estimating Kvaal age is based on secondary dentin formation, where secondary dentin formation has a strong correlation with chronological age because the process takes place regularly and continuously throughout life (Kvaal et al., 1995; Li et al., 2019; Li et al., 2020). This method has been tested and proven to be quite accurate in other populations (Li et al., 2020). The correlation assessment of maxillary and mandibular canines with chronological age, where the right side maxillary canine had the strongest correlation, while the right side mandibular canine had the weakest correlation and which side difference was better could not be established (Li et al., 2020).

Orthopantomography (OPG) is one of the extraoral imaging techniques performed at the Radiology Installation at dr. Moewardi in dental and oral polyclinic and emergency referral patients. This technique visualizes the arrangement of the teeth and the anatomy of the mandibular bones. From the visualized tooth arrangement, canines are a good sample to measure because (1) it is often found in adults, (2) it has better resistance than other anterior teeth, and (3) the largest pulp chamber (Az, 2016).

The purpose of this study was to determine the difference in age estimates using the Kvaal method on the right and left mandibular canines.

\section{SUBJECTS AND METHOD}

\section{Study Design}

This study was conducted in the form of an analytic observational study with a cross sectional approach, which was held at the Radiology Installation at Dr. Moewardi Hospital, Surakarta from July to December 2020.

\section{Population and Sample}

The subjects of this study were 80 orthopantomogram samples at the Radiology Installation at Dr Moewardi Hospital, Surakarta. The samples were selected based on inclusion criteria, namely: right and left mandibular canines with pulpal cavity and root canal views. While the exclusion criteria were teeth treated with root canals, caries, periodontitis, periapical lesions, impacted or rotated teeth and teeth with orthodontic appliances.

\section{Study Variable}

The dependent variable was the age estimated by the Kvaal method on the right and left mandibular canines.

\section{Operational Definition of Variables}

The estimated age was obtained by entering the tooth measurement ratio into the Kvaal formula. Measurement ratios are obtained by measuring tooth length, pulp length, root length, and root width.

\section{Data Analysis}

The data were tested by using the T-test to look for differences between the two dependent variables.

\section{Ethical Worthiness}

The letter of ethical clearance was issued by the Health Research Ethics Commission of Dr. Moewardi Hospital, Surakarta with letter number: 1.273 / XI / HREC / 2020.

\section{RESULTS}

1. Sample Characteristics

This study involved 80 subjects. The data on the characteristics of the research sample are presented in table 1 based on gender, and table 2 measurements of the right and left canines. Based on gender, in this study there were 40 (50\%) male subjects and 40 (50\%) female subjects. 
Kusumaningrum et al./ Age Estimated by the Kvaal Method on Right and Left Mandibular Canines

Table 1. Sample Characteristics Based on Gender

\begin{tabular}{lcc}
\hline Demographic Variables & Total (n) & Percentage (\%) \\
\hline Gender & & \\
Male & 40 & 50,0 \\
Female & 40 & 50,0 \\
\hline
\end{tabular}

Based on the characteristics of the right canine teeth in Table 2, the average pulp width/ root pulp ratio at level $\mathrm{A}$ is 0.17 (Mean $=0.17 ; \mathrm{SD}=0.04$ ), at level $\mathrm{B}$ is 0.1 (Mean=0.18; $\mathrm{SD}=0.38$ ), and at level $\mathrm{B}$ is $0.1($ Mean $=0.18 ; \mathrm{SD}=0.38)$. Level $\mathrm{C}$ is 0.17 (Mean $=0.17 ; \mathrm{SD}=0.46$ ). The mean ratio of pulp length to tooth length $(\mathrm{R})$ was 0.75 $(\mathrm{Mean}=0.75 ; \mathrm{SD}=0.04)$, the average ratio of pulp length to root length $(\mathrm{P})$ was 1.08 (Mean=1.08; $\mathrm{SD}=0.05)$, and the mean ratio of pulp length to root length $(\mathrm{P})$ was 1.08 (Mean=1.08; $\mathrm{SD}=0.05)$. - The average ratio of tooth length to root length $(\mathrm{T})$ was 1.45 (Mean=1.45; $\mathrm{SD}=0.09)$. The average of the five ratios $(\mathrm{M})$ is 0.47 (Mean $=0.47$; $\mathrm{SD}=0.03$ ).

Table. 2 Measurement of Tooth Size Ratio

\begin{tabular}{lcccc}
\multicolumn{1}{c}{ Ratio } & \multicolumn{2}{c}{ Right Canines } & \multicolumn{2}{c}{ Left Canines } \\
\cline { 2 - 5 } & Mean & SD & Mean & SD \\
\hline $\begin{array}{l}\text { A: ratio of pulp width to root width at enamel } \\
\text { cementum junction (ECJ) }\end{array}$ & 0.17 & 0.04 & 0.17 & 0.04 \\
$\begin{array}{l}\text { B: ratio of pulp width to root width between } \\
\text { levels A and C }\end{array}$ & 0.18 & 0.38 & 0.18 & 0.43 \\
C: ratio of pulp width to root width between apex & 0.17 & 0.46 & 0.18 & 0.05 \\
and ECJ & & & & \\
R: ratio of pulp length to tooth length & 0.75 & 0.04 & 0.74 & 0.09 \\
P: ratio of pulp length to root length & 1.08 & 0.05 & 1.09 & 0.05 \\
T: the ratio of tooth length to root length & 1.45 & 0.09 & 1.46 & 0.09 \\
M: mean of (R + P + A + B + C) / 5 & 0.47 & 0.03 & 0.47 & 0.03 \\
\hline
\end{tabular}

\section{Estimated Age of Right and Left Mandibular Canines}

Based on the Kvaal equation, calculations were made on the right and left mandibles of each subject. The means of estimated right and left mandibular canines were then compared to see if they were matched between right and left. The analysis showed
Based on the characteristics of the left canine teeth in table 2, the average pulp width/ root pulp ratio at level $\mathrm{A}$ is 0.17 (Mean $=0.17 ; \mathrm{SD}=0.04$ ), at level $\mathrm{B}$ is 0.18 (Mean $=0.18 ; \mathrm{SD}=0.43$ ), and at level $\mathrm{B}$ is 0.18 (Mean= 0.18; $\mathrm{SD}=0.43$ ). Level $\mathrm{C}$ was 0.18 (Mean= 0.18; $\mathrm{SD}=0.05)$. The mean ratio of pulp length to tooth length $(\mathrm{R})$ was 0.74 (Mean= 0.74; $\mathrm{SD}=0.09$ ), the mean ratio of pulp length to root length $(\mathrm{P})$ was 1.09 (Mean=1.09; $\mathrm{SD}=0.05$ ), and the mean ratio was 1.09 . The average ratio of tooth length to root length (T) was 1.46 $(\mathrm{Mean}=1.46 ; \mathrm{SD}=0.09)$. The average of the five ratios $(\mathrm{M})$ is 0.47 (Mean $=0.47$; $\mathrm{SD}=$ o.03). 


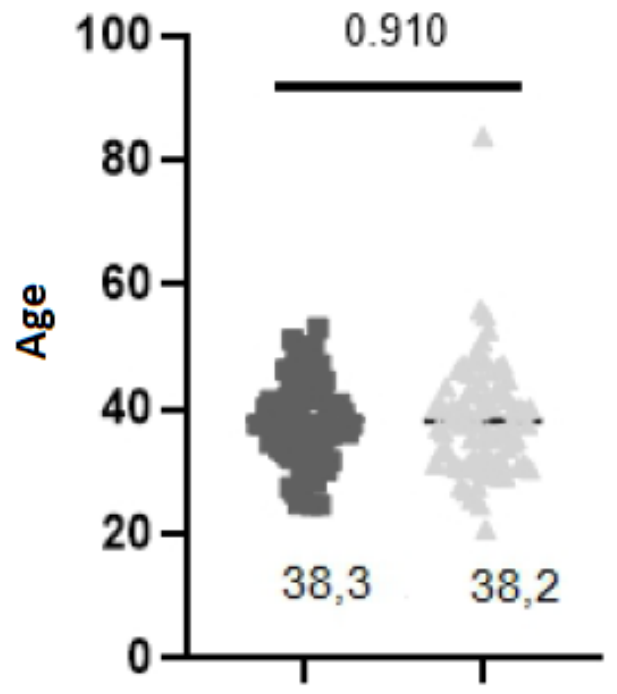

\section{Right canines estimation Left canines estimation}

\section{Figure 1. Comparison of Estimated Age of Right and Left Mandibular Canines}

\section{DISCUSSION}

Age estimates using teeth are increasingly accepted at this time because the resulting age estimates are less varied, especially when compared to indicators of bone and sexual maturity (Stavrianos et al., 2008). Gustafson first developed and introduced a systematic method of estimating age using teeth for adults. Tore Solheim first measured secondary dentine deposition in the histological sections of the tooth and found the results to have a strong correlation with the age of the subject (Singh et al., 2004). Secondary dentin deposition can be an indicator of age on periapical radiographs of the whole mouth with statistically significant results (Kvaal et al., 1995).

This study determines the estimated age of a person based on teeth by measuring the results of panoramic radiographs using the Kvaal calculation method. The Kvaal calculation method was successfully applied to different radiographic methods without showing a significant difference, namely panoramic radiography (Bosmans et al., 2005 and Paewinsky et al., 2005). Panoramic radiography is a method of exa-
\end{abstract}

mination that does not require repeated oral radiographs, can be applied to live humans, and does not require tooth extraction. This method can be used for individuals over 21 years of age, where bone growth and development has stopped. The accuracy of this method depends on the measurement precision as well as the quality of the panoramic photo. Several factors, such as caries, dental filling, and intra- and inter-observer errors, can influence the interpretation of the estimated age (Paewinsky et al., 2005). The advancement of the digital panoramic photo method has greatly improved in the last decade and has become the accepted method of examination for making clinical decisions in dentistry. Therefore, the use of panoramic radiography in this study to calculate the estimated age of individuals based on teeth by the Kvaal method is a method that can be used and has been proven in previous studies.

The right and left mandibular canines are the options for calculating the estimated age based on the Kvaal method for several reasons, namely they are often found in 
adults, have better resistance than other anterior teeth, and have the largest pulp space compared to other teeth (Whitley et al., 2005; John, 2011 and Az AIS, 2016). Left and right mandibular canines were included in this study to compensate for magnification and angulation errors that led to different ratios (Kvaal et al., 1995). Therefore, the use of canines to determine the estimated age of an individual based on the Kvaal method is a method that has a high compatibility with individual chronological age. The results of this study showed that there was no statistically significant difference between the estimated age of right and left mandibular canines based on the Kvaal method $(\mathrm{p}=0.910)$. The study of Kvaal (1995), which is the first study to find the Kvaal formula for age estimation, did not show any difference in age estimation between right and left mandibular teeth. Age estimation with canines using the Kvaal method did not show a difference between the left and right mandibles and was an option that did not have a signifycant difference with actual age (Sharma and Srivastava, 2020). Age estimates with teeth did not show any difference between left and right teeth, including canines (Mittal et al., 2016). The estimated age can be measured in either the right or left mandibular canines.

\section{AUTHOR CONTRIBUTION}

Sulistyani Kusumaningrum, Brian Wasita, Hari Wujoso, Rachmi Fauziah Rahayu, Muhamad Lukman Hermansyah and Tharina Lawei collected and analyzed data and wrote manuscripts.

\section{CONFLICT OF INTEREST}

There is no conflict of interest in this study.

\section{FUNDING AND SPONSORSHIP}

This study is self-funded.

\section{ACKNOWLEDGEMENT}

The author would like to thank Dr. Moewardi Hospital, Surakarta for giving permission to collect data.

\section{REFERENCE}

Adams C, Carabott R, Evans S (2014). Forensic odontology an essential guide. West Sussex: John Wiley and Sons, Ltd.

$\mathrm{Az}$ AIS (2016). Estimasi umur kronologis manusia berdasarkan gambaran foto panoramik gigi menggunakan metode Schour dan Masseler (Estimation of human chronological age based on panoramic photographs of teeth using the Schour and Masseler method). Fakultas Kedokteran Gigi Universitas Hasanuddin. Makasar.

Bosmans N, Ann P, Aly M, Willems G (2005). The application of Kvaal's dental age calculation technique on panoramic dental radiographs. Forensic Sci Int. 153(2-3): 208-12 https://doi.org/10.1016/j.forsciint.2004.08 .017 .

John RP (2011). Textbook of dental radiology second edition. New Delhi: Jaypee Brothers Medical Publishers (P) Ltd.

Kvall SI, Kolltveit KM, Thomsen IO, Solheim $\mathrm{T}$ (1995). Age estimation of adults from dental radiographs. Forensic Sci Int. 74(3): 175-185. https://doi.org/10.1016/0379-0738(95)o1760-g.

Li MJ, Chu G, Han M, Chen T, Zhou H, Guo $\mathrm{Y}$ (2019). Application of the Kvaal method for age estimation using digital panoramic radiography of Chinese individuals. Forensic Sci Int. 301: 76 81. https://doi.org/10.1016/j.forsciint.2019.05.015.

Li MJ, Zhao J, Chen W, Chen X, Chu G, Chen T, Guo Y (2020). Can canines 
Kusumaningrum et al./ Age Estimated by the Kvaal Method on Right and Left Mandibular Canines

alone be used for age estimation in chinese individuals when applying the kvaal method?. Forensic Sci Int. 1 - 6. https://doi.org/10.1080/20961790.2 020.1717029 .

Madea B (2014). Handbook of forensic medicine. John Wiley and Sons, Ltd. West Sussex.

Miles AEW (2001). The miles method of assessing age from tooth wear revisited. J Archaeol Sci. 28(9): 973-982. https://doi.org/10.1006/jasc.2000.06 52.

Mittal S, Nagendrareddy SG, Sharma ML, Agnihotri P, Chaudhary S, Dhillon M (2016). Age estimation based on Kvaal's technique using digital panoramic radiographs. J Forensic Dent Sci. 8(2): 115. https://dx.doi.org/10.4103\%2Fo975-1475.186378.

Paewinsky E, Pfeiffer H, Brinkmann B (2005). Quantification of secondary dentine formation from orthopantamograms - A contribution to forensic age estimation methods in adults. Int J Legal Med. 119(1): 27-30. https://doi.org/10.1007/s00414-004-0492-X.

Priyadarshni C, Uma SR, Puranik M (2015).

Dental age estimation methods: A review. Int J Adv Health Sci. 1(12): 19 -25 .

Putri AS, Nehemia B, Soedarsono N (2013). Prakiraan usia individu melalui pemeriksaan gigi untuk kepentingan forensik Kedokteran Gigi (Prediction of individual age through dental examination for dentistry forensic purposes). Jurnal PDGI. 63(3): 55 - 63.

Senn DR, Stimson PG (2010). Forensic Dentistry. Second Edition. Boca Raton: CRC Press.

Sharma R, Srivastava A (2020). Radiographic evaluation of dental age of adults using Kvaal's method. J Forensic Dent Sci. 2(1): 22 - 26. https://doi.org/10.4103/0974-2948.71053.

Singh A, Gorea RK, Singla U. 2004. Age estimation from the physiological changes of teeth. JIAFM. 26: 94-6.

Stavrianos CH, Mastagas D, Stavrianous I, Karaiskou O (2008). Dental age estimation of adults: A review of methods and principles. Research $\mathrm{J}$ Med Sci. 2(5): 258-68. https://medwelljournals.com/abstract/?doi=rjmsci.2008. 258.268.

Stimson PG and Mertz CA (1997). Forensic Dentistry. Boca Raton: CRC Press. 